\title{
NR1H4 Gene
}

National Cancer Institute

\section{Source}

National Cancer Institute. NR1H4 Gene. NCI Thesaurus. Code C114908.

This gene is involved in bile acid binding and metabolism. 